\title{
The genus Desmometopa Loew (Diptera, Milichiidae) of Japan
}

\author{
Mitsuhiro Iwasa \\ Laboratory of Entomology, Obihiro University of Agriculture and Veterinary Medicine, \\ Inada-cho, Obihiro, Hokkaido, 080 Japan
}

(Received: 21 August 1996; Accepted: 9 October 1996)

Key words: Diptera, Milichiidae, Desmometopa, new records, Japan

\begin{abstract}
The Japanese species of the genus Desmometopa Loew are revised. Of three known species from Japan, two species reported as $D$. tarsalis Loew and $D$. tristicula Hendel are proven to be $D$. microps Lamb and $D$. sordida Fallén, respectively. Two species, $D$. m-nigrum (Zetterstedt) and $D$. varipalpis Malloch are newly recorded from Japan. Short redescriptions of five species are added with illustrations of head, pleuron and male genitalia. A key to the Japanese species is presented.
\end{abstract}

\section{INTRODUCTION}

The flies of the genus Desmometopa Loew are distributed in all faunal regions. The adults are found in the vicinity of the cattle house, sewage and decaying material, and they frequently visit flowers. Some species are synanthropic and often enter houses, rooms and latrines, attracted to some odors (Sabrosky, 1983). In Japan, some species are known to enter the food factory and to be attracted to a certain organic solvent. The larvae are saprophagous or coprophagous, feeding on dung, manure, compost, sewage and a wide variety of decaying material.

After Hennig's revision (1937), the Palaearctic and Oriental species were catalogued by Papp (1984) and Sabrosky (1977), respectively. The world Desmometopa were reviewed by Sabrosky (1983) and Papp (1993) added one species from the Palaearctic Region. In Japan Fukuhara (1965) listed only specific names of 3 species, but thereafter there is virtually no taxonomic work of the Japanese Desmometopa.

In the present paper, I revise the Japa- nese species of the Desmometopa with 2 newly recorded species and give an identification key for the Japanese species.

\section{Genus Desmometopa Loew} [Japanese name: Kurokobae-zoku]

Desmometopa Loew, 1866, Berlin Ent. Ztschr. (1865) 9: 184. Type-species: Agromyza m-atrum Meigen, 1830: Syst. Beschr. 6: 170 (by designation of Hendel, 1903: Wien. Ent. Ztg. 22: 251 [=sordida (Fallén, 1820)].

Diagnosis. Eyes large; frons with black M-shaped frontal vitta delineated by the frontal triangle and the fronto-orbital and inter frontal plates (Fig. 1); each frontoorbital plate with 2 lateroclinate upper orbital and 2 or 3 mesoclinate lower orbital setae; antennae usually small; thorax black, with grayish pollen; mesonotum densely covered with short bristles; pleuron usually bare and with polished areas; subcostal break not deeply incised; legs without striking characteristics; male epandrium bears surstyli which are comparatively slender; male cerci unusually large. 


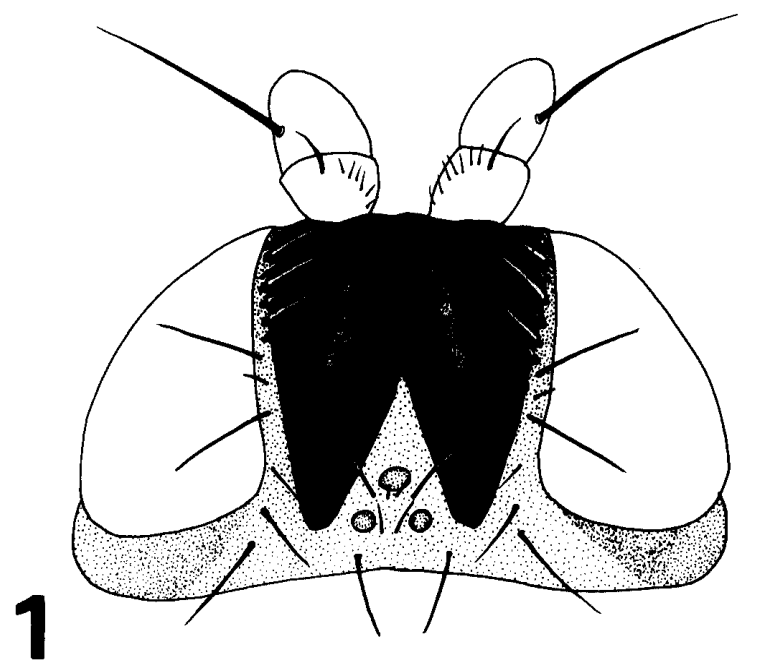

Fig. 1. Male head of Desmometopa microps, dorsal view.

Key to the Japanese species of the genus Desmometopa (궁)

1. Gena strikingly broad, exceeding $1 / 4$ height of an eye (Fig. 2); polished spot on pleuron relatively large and bilobed anterodorsally (Fig. 8) .............. .........D. m-nigrum (Zetterstedt)

- Gena not strikingly broad, not exceeding $1 / 4$ height of an eye; polished spot on pleuron small and not bilobed ....2

2. Postgenal area broad in both sexes (Figs. 3, 4), and in male postorbital area broad to vertex; basal one-third of palpi light brown .......... microps Lamb

- Postgenal area not broad in both sexes

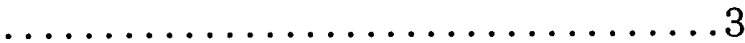

3. Knob of halter brown to black; gena black in ground color and subocular crescent shining and distinct; palpi clavate and wholly black in both sexes (Fig. 5) ........... sordida (Fallén)

- Knob of halter yellow to light brown; gena yellow to brown; male palpi broadly expanded and capitate or fusiform .........................4

4. Gena yellowish in ground color and comparatively narrow about $1 / 7$ to $1 / 8$ height of an eye; male palpi capitate, rounded distally (Fig. 6) ............ ........... singaporensis Kertész

- Gena brownish in ground color and comparatively broad about $1 / 5$ to $1 / 6$ height of an eye (Fig. 7); male palpi fusiform ....... varipalpis Malloch

Desmometopam-nigrum (Zetterstedt, 1848)

(Japanese name: Hohobuto-kurokobae)

Figs. 2, 8, 11, 12

Agromyza m-nigrum Zetterstedt, 1848, Dipt. Scand. 7: 2743.

Desmometopa m-nigrum: Malloch, 1924, Proc. Linn. Soc. N. S. Wales 49: 331.

$\sigma$ 우. 1st and 2nd antennal segments dark brown, 3rd segment black; gena especially broad, exceeding $1 / 4$ height of an eye and with large triangular polished subocular crescent (Fig. 2); postgena also with polished area; palpi clavate and yellow, only apical area black (Fig. 2); mesonotum and pleuron black, with dark grayish pollen; large bilobed shining spot present in area from anterior part of sternopleuron to mesopleuron (Fig. 8); wings hyaline, slightly tinged with milky white; halteres yellow; all legs black; abdomen black, with grayish pollen; male epandrium broad in lateral view (Fig. 11); male cerci large and expanded (Figs. 11, 12).

Specimens examined. [Hokkaido]$24 \sigma^{7}, 10$ 우, Obihiro, 19 July 1994, M. Iwasa; $49 \sigma^{\nearrow}, 4$ 우, same locality, 21 July 1994, M. Iwasa.

Distribution. Cosmopolitan. New to Japan (Hokkaido).

Bionomics. The adult flies were mainly collected on flowers neighboring the swine hut. Chicken dung is known as rearing medium of this species (Sabrosky, 1983).

Remarks. This species is a distinctive member of the genus in having unusual broad genae.

Desmometopa microps Lamb, 1914

[Japanese name: Minami-kurokobae] Figs. 1, 3, 4, 9, 13

Desmometopa microps Lamb, 1914, Trans. Linn. Soc. London, Ser. 2 (Zool.) 16: 364. Desmometopa microps: Sabrosky, 1983, Contr. Amer. Ent. Inst. 19: 25; Papp, 1984, Catalog. Dipt. Palae. Reg. 10: 114. 


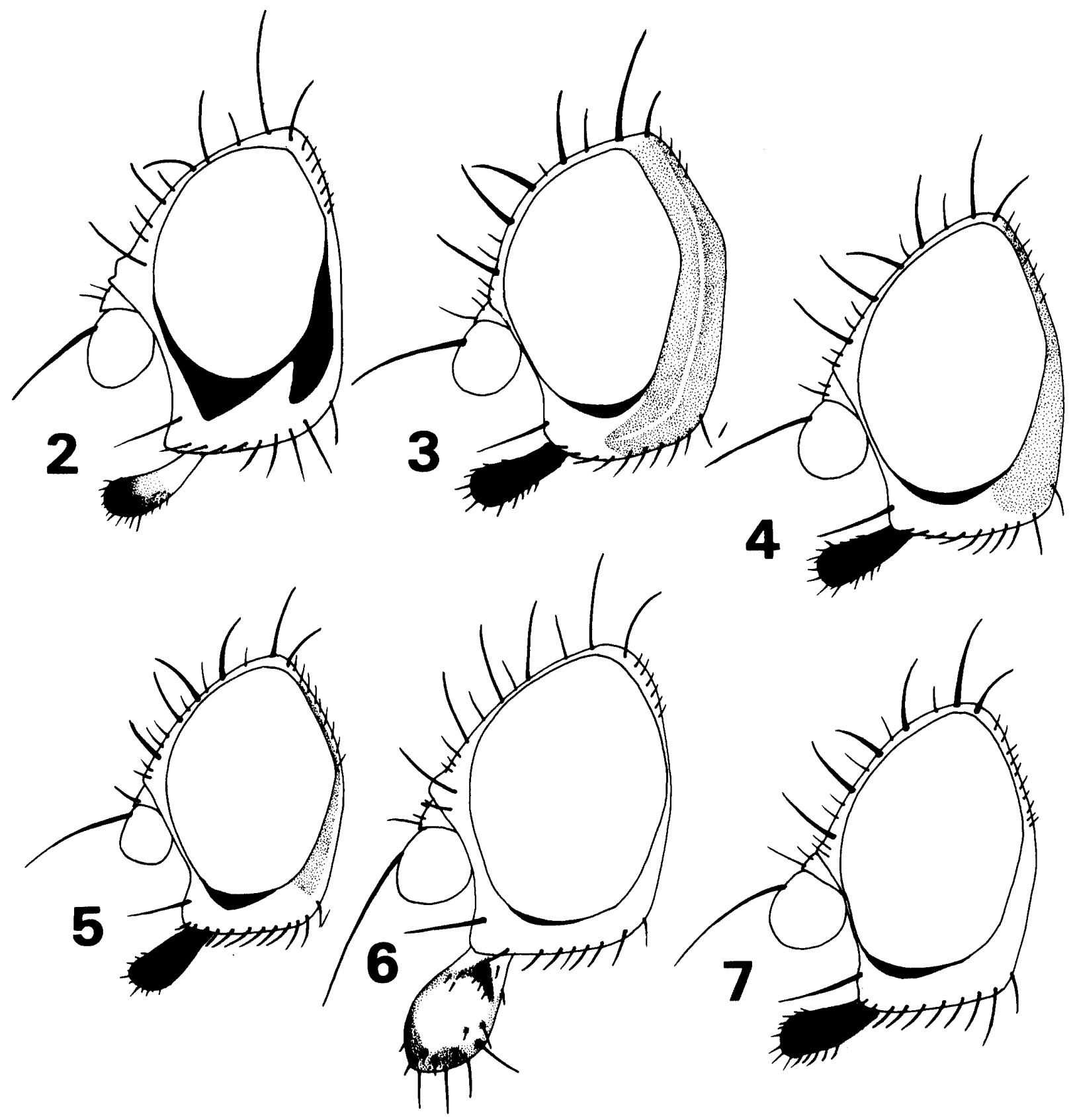

Figs. 2-7. Head, lateral view - 2, Desmometopa m-nigrum; 3, D. microps (male); 4, D. microps (female); $5, D$. sordida; $6, D$. singaporensis; $7, D$. varipalpis.

주우. Head black; frons with M-shaped frontal vitta subshining velvet black (Fig. 1); antennae wholly black; postgenal area broad and subshining in both sexes (Figs. 3,4 ; dotted area) and in male postorbital area broad to vertex (Fig. 3); palpi clavate and black, only basal one-third light brown (Figs. 3, 4); mesonotum and pleuron black, with dark grayish pollen; shining spot in area from anterior part of sternopleuron to mesopleuron rounded lozenge- shaped (Fig. 9); wings hyaline; halteres brown; all legs black; abdomen black, with grayish pollen; male epandrium like as Fig. 13; posterior view of epandrium and cerci similar to those of sordida (Fig. 15).

Specimens examined. [Hokkaido]$1 \sigma^{7}, 1$ 우, Memuro, 12 June 1988, A. Iwasaki; $2 \sigma^{\nearrow}$, Toyonuka, 3 July 1978, M. Iwasa; $10^{7}, 1$ 우, Obihiro, 23 July 1994, M. Iwasa; 3厅', 10 우, Obihiro, 1-5 Aug. 1994, M. Iwasa. [Honshu]-1 $\sigma^{7}, 1$ ㅇ, Nurukawa, 

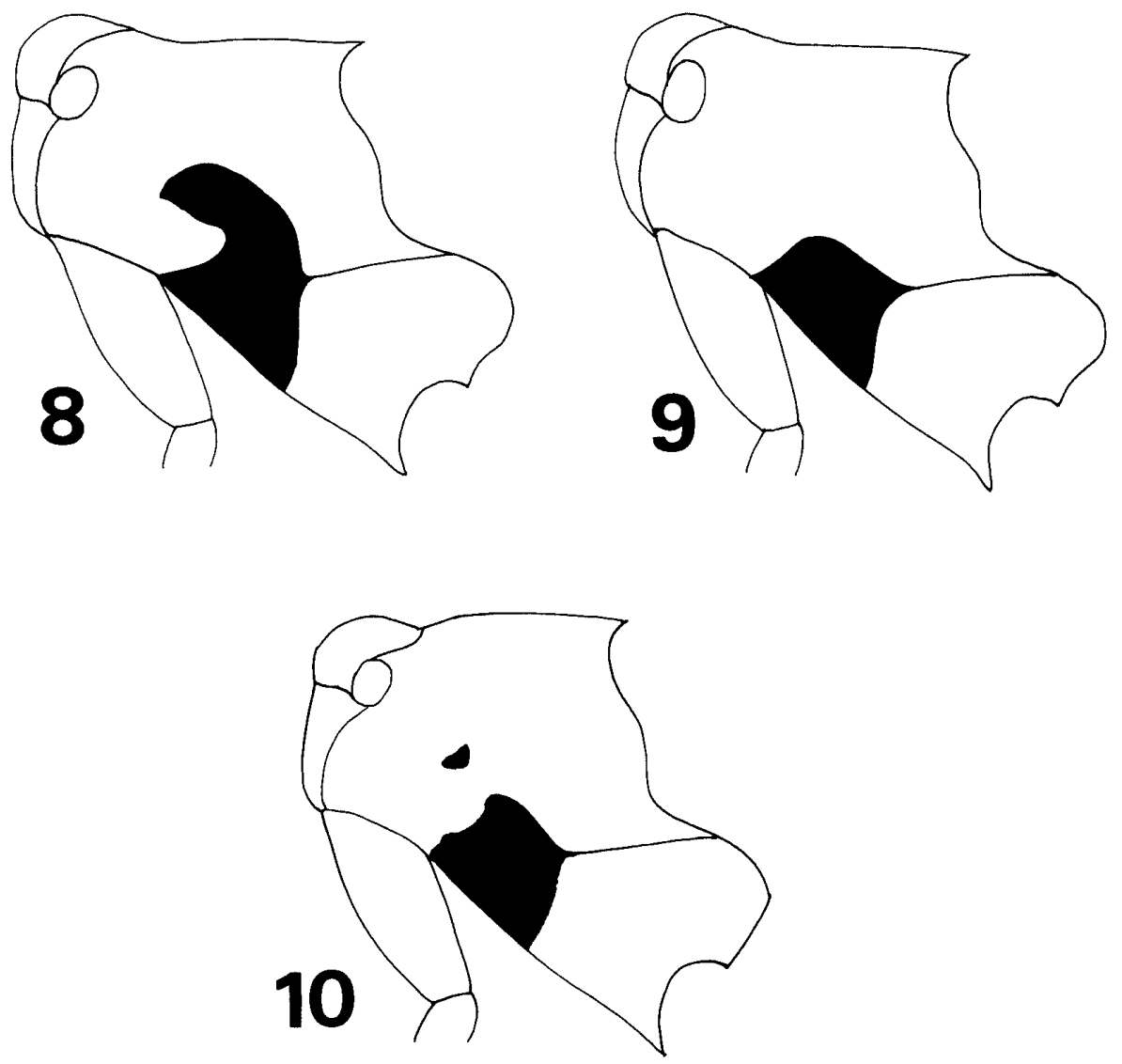

Figs. 8-10. Thoracic pleuron (left) - 8, Desmometopa m-nigrum; 9, D. microps; 10, D. sordida.

Aomori Pref., 5 Aug. 1953, S. Kato; $4 \sigma^{\nearrow}$, 5 우, Hayachine, Iwate Pref., 29 Jul. 1970, T. Saigusa; $1 \sigma^{7}$, Maoka, Tochigi Pref., 7 Aug. 1981, K. Kanmiya; 3ð, Tokyo, 26 Jul. 1953, N. Fukuhara; 3o', Tokyo, 24-25 Aug. 1954, N. Fukuhara. [Kyushu]-72 $\sigma^{\top}$, 10 우, Nii, Tsushima Is., Nagasaki Pref., 20 Sept. 1970, K. Kanmiya; $12 \sigma^{\nearrow}$, 3 우, Kuwa, same locality, 21 Oct. 1970, K. Kanmiya; $5 \sigma^{7}, 2$ 우, Aji, same locality, 20 Oct. 1970, K. Kanmiya; $3 \sigma^{\top}, 3$ 우, Tsutsu, same locality, 21 Oct. 1970, K. Kanmiya; $2 \sigma^{\nearrow}$, Kurume, Fukuoka Pref., 5 May 1975, K. Kanmiya. [Ryukyu Is.] -4 $\sigma^{\top}$, Funaura, Iriomote Is., 15 May 1991, K. Kanmiya; $1 \sigma^{7}, 1$ 우, Sonai, Iriomote Is., 15 Mar. 1991. K. Kanmiya; $2 \sigma^{7}, 8$ 우, Ishigaki Is., 12 Oct. 1988, K, Kanmiya.

Distribution. Afrotropical and Oriental Regions and bordering area of south $\mathrm{Pa}$ laearctic Region. Japan (Hokkaido, Honshu, Kyushu and Ryukyu Is.).

Bionomics. This species is commonly found in the vicinity of the cattle house and sewage water throughout Japan. The adults frequently visit flowers.

Desmometopa sordida (Fallén, 1820) [Japanese name: Hime-kurokobae]

Figs. 5, 10, 14, 15

Madiza sordida Fallén, 1820, Oscinides Sveciae, p. 10.

Desmometopa sordida: Sabrosky, 1983, Contr. Amer. Ent. Inst. 19: 47; Papp, 1984, Catalog. Palae. Reg. 10: 114.

구우. Head black; frons with M-shaped frontal vitta subshining velvet black; antennae wholly black; gena nearly $1 / 6$ height of an eye, with rounded subocular crescent (Fig. 5); palpi clavate and wholly black (Fig. 5); mesonotum and pleuron black, with dark grayish pollen; a large shining spot and a small shining dot present in area from anterior part of sternopleuron to mesopleuron (Fig. 10); wings hyaline; halteres brown, darkened basally; coxae, femora and tibiae black; tarsi light 

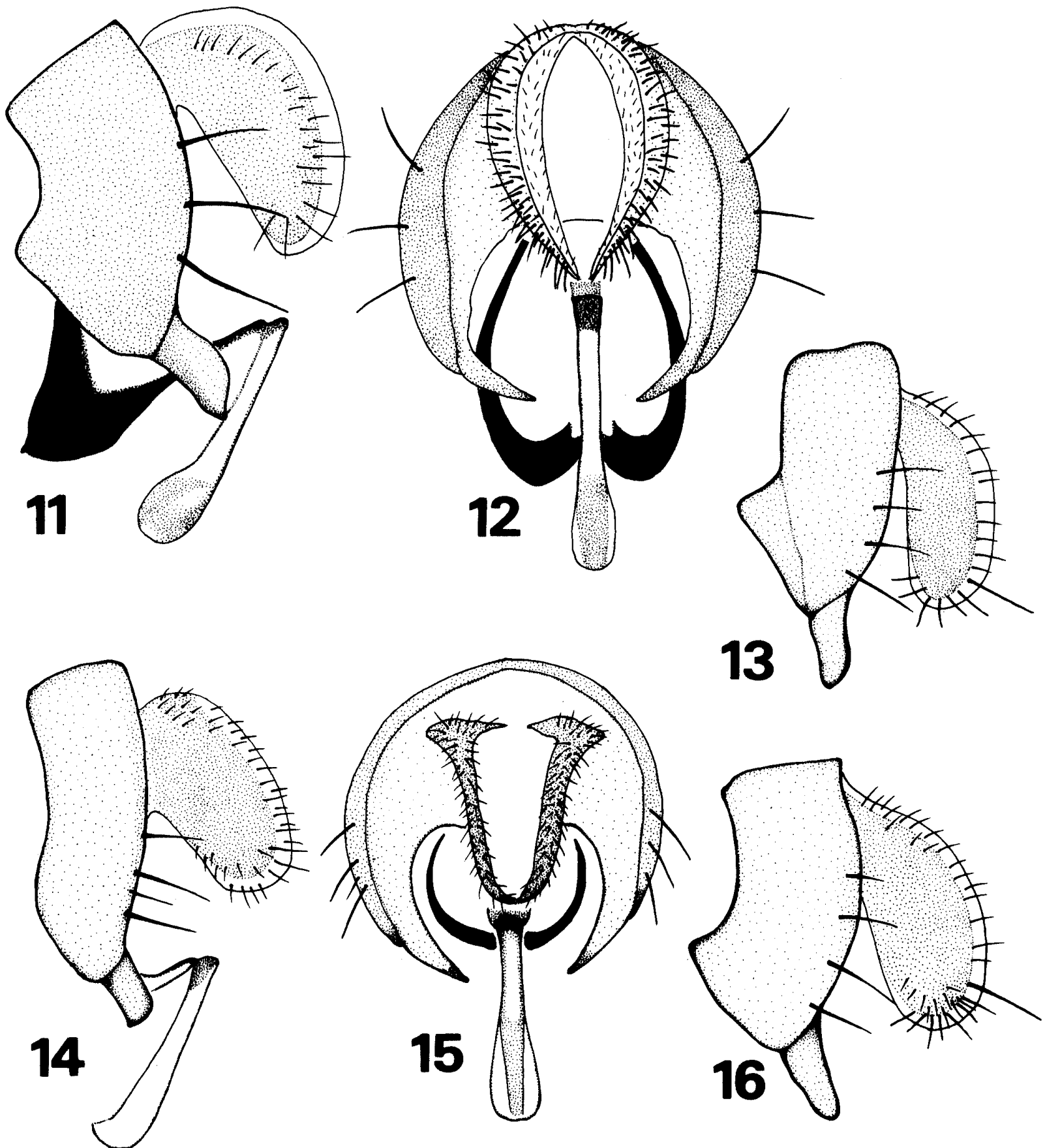

Figs. 11-16. Male genitalia — 11, Desmometopa m-nigrum, lateral view (left); 12, ditto, posterior view; $13, D$. microps, lateral view (left); $14, D$. sordida, lateral view (left); 15 , ditto, posterior view; 16, D. singaporensis, lateral view (left).

brown, darkened in 4th and 5th segments; abdomen black, with grayish pollen; male epandrium slender in lateral view (Fig. 14).

Specimens examined. [Hokkaido]$20 \sigma^{7}, 5$ 우, Obihiro, 23 Jul. 1994, M. Iwasa; $2 \sigma^{7}, 3$ 우, Obihiro, 1 Aug. 1994, M. Iwasa. [Honshu]-1 $1 \sigma^{7}, 1$ 우, Kyoto, ? June 1964, S. Ishii. [Kyushu]-4 $4 \sigma^{7}$, Mt. Korasan, Kuru- me, Fukuoka Pref., 8 May 1978, K. Kanmiya; $5 \sigma^{\circ}, 1$ 우, Nii, Tsushima Is., Nagasaki Pref., 20 Sept. 1972, K. Kanmiya; $2{ }^{\nearrow}, 5$ 우, Kuwa, same locality., 21 Oct. 1970, K. Kanmiya; $1 \sigma^{7}, 4$ 우, Tsutsu, same locality, 21 Oct. 1970, K. Kanmiya. [Ryukyu Is.]-2 우, Ishigaki Is., 12 Oct. 1988, K. Kanmiya.

Distribution. Palaearctic and Holarctic Regions. Japan (Hokkaido, Honshu, Kyu- 
shu and Ryukyu Is.).

Bionomics. The adult flies were collected on flowers near hen house. They were also attracted to odor of a certain organic solvent.

Remarks. Females of $D$. sordida Fallén and D. microps Lamb are often indistinguishable in teneral specimens with collapsed gena, but the former can be distinguished from the latter by having wholly black palpi.

Desmometopa singaporensis Kertész, 1899 [Japanese name: Yamato-kurokobae] Figs. 6,16

Desmometopa singaporensis Kertész, 1899, Természetr. Füz. 22: 194.

Desmometopa tristicula Hendel, 1914, Suppl. Ent. 3: 96.

Desmometopa palpalis de Meijere, 1914, Tijd. Ent. 57: 251.

Desmometopa singaporensis: Sabrosky, 1983, Contr. Amer. Ent. Inst. 19: 44; Papp, 1984, Catalog. Palae. Reg. 10: 114. 万'. Head black; frons with M-shaped frontal vitta subshining velvet black; fronto-orbital plates relatively narrow; antennae wholly black; gena not broad, about 1/10 height of an eye (Fig. 6); palpi yellow, broadly expanded, and with brownish pattern (Fig. 6); mesonotum and pleuron black, with dark grayish pollen; shape of shining spot in area from anterior part of sternopleuron to mesopleuron similar to that of microps (Fig. 9); wings hyaline; halteres yellow, darkened basally; all legs black; abdomen with grayish pollen; male epandrium like as Fig. 16 in lateral view; posterior view of male epandrium and cerci similar to those of sordida (Fig. 16).

Specimens examined. [Honshu]-107, Nishiikuta, Kanagawa Pref., 10 Oct. 1961, N. Fukuhara. [Kyushu]-2 $\sigma^{7}$, Nii, Tsushima Is., Nagasaki Pref., 20 Sept. 1972, K. Kanmiya; $1 \sigma^{7}$, Kuwa, same locality, 21 Oct. 1970, K. Kanmiya. [Ryukyu Is.]-1 $\sigma^{7}$, Ohtomi, Iriomote Is., 13-15 Oct. 1988, K. Kanmiya.
Distribution. Widely distributed in the Old World Tropics, the Pacific Islands and Neotropical Region. Japan (Honshu, Kyushu and Ryukyu Is.).

Bionomics. This species is rare in Japan. According to Sabrosky (1983), this species was collected on decaying giant African snail and human excrement.

Desmometopa varipalpis Malloch, 1927 [Japanese name: Nami-kurokobae] Fig. 7

Desmometopa varipalpis Malloch, 1927, Proc. Linn. Soc. N. S. Wales 52: 7.

Desmometopa varipalpis: Sabrosky, 1983, Contr. Amer. Ent. Inst. 19: 41; Papp, 1984, Catalog. Palae. Reg. 10: 115.

ㅇ․ Head black; frons with M-shaped frontal vitta subshining velvet black; antennae wholly black; gena not broad, about $1 / 7$ height of an eye and with narrow polished subocular crescent (Fig. 7); palpi clavate, anteroventrally black and posterodorsally yellow (Fig. 7); mesonotum and pleuron black, with dark grayish pollen; shape of shining spot in area from anterior part of sternopleuron to mesopleuron similar to that of microps (Fig. 9); wings hyaline; halteres yellow, darkened basally; femora and tibiae black, but middle and hind 1st to 3rd tarsi yellow; abdomen black with grayish pollen.

$\sigma^{7}$. Not available. According to Sabrosky (1983), male palpi are yellow, broadly expanded and fusiform.

Specimens examined. [Hokkaido]1 우, Sapporo, 25 Aug. 1986, A. Iwasaki; 1 우, Sapporo, 2 Sept. 1986, A. Iwasaki. [Honshu]-1우, Hirosaki, Aomori Pref. 4 Aug. 1953, I. Hattori; 1 우, Nishigahara, Tokyo, 14 Sept. 1960, N. Fukuhara; 1 우, same locality, 30 Aug. 1961, N. Fukuhara; 1 우, same locality, 8 Oct. 1962, N. Fukuhara; 1 우, same locality, 2 Sept. 1967, N. Fukuhara; 1 우, same locality, 5 Aug. 1968, N. Fukuhara; 5 우, Suginami, Tokyo, 26 Jul. 1953, N. Fukuhara; 2 우, Hatsudai, Tokyo, 15 Aug. 1962, T. Okazaki. [Kyushu]-6우, 
Nii, Tsushima Is., Nagasaki Pref., 20 Sept. 1972, K. Kanmiya. [Ryukyu Is.]-2 우, Ishigaki Is., 12 Oct. 1988, K. Kanmiya.

Distribution. Widely distributed in all faunal regions. New to Japan (Hokkaido, Honshu, Kyushu and Ryukyu Is.).

Bionomics. Unknown in Japan. It is known that the adult flies are attracted to some odors; they enter operating and surgery rooms in hospital and a dairy cheese room; and also gather around outdoor latrine, septic tank and sewage water (Sabrosky, 1983).

Remarks. Females of $D$. varipalpis Malloch and $D$. singaporensis Kertész are closely similar each other, but they are distinguishable by the characteristics mentioned in the key if the specimens are not teneral.

\section{ACKNOWLEDGEMENTS}

I wish to express my sincere thanks to $\mathrm{Mr}$. N. Fukuhara of the National Institute of AgroEnvironmental Sciences and Dr. C. W. Sabrosky of U.S.A. for their kind help in identification of specimens used and in offering the valuable materials. I am grateful to Drs. K. Kanmiya of Kurume University; M. Suwa and S. Takagi of Hokkaido University; T. Matsumura of the National Institute of AgroEnvironmental Sciences; A. Iwasaki of Hokkaido Kitami Agricultural Experiment Station; T. Saigusa of Kyushu University, for their kindness in offering the valuable materials. I also would like to express my hearty thanks to Prof. K. Hori of Obihiro University of Agriculture and Veterinary Medicine for his continuous encouragements. Contribution No. 168 from the Laboratory of Entomology, Obihiro University of Agriculture and Veterinary Medicine.

\section{REFERENCES}

Fukuhara, N. (1965) Milichiidae. In: Major pests of economic plants in Japan, pp. 321-322, Japan Plant
Protection Association, Tokyo (in Japanese).

Hennig, W. (1937) Milichiidae et Carnidae. In: Die Fliegen der palaearktischen Region (ed., Lindner, E.), Vol. 60a, pp. 1-91, Schweizerbart, Stuttgart.

Papp, L. (1984) Family Milichiidae. In: Catalogue of Palaearctic Diptera (ed., Sobs, A. and L. Papp), Vol. 10, pp. 110-118, Elsevier Sci. Pub., Budapest.

Papp, L. (1993) Three new milichiid species (Diptera, Milichiidae) from Hungary. Annls Hist.-Nat. Mus. Natn. Hung., 85: 133-139.

Sabrosky, C. W. (1977) Family Milichiidae. In: Cata log of the Diptera of the Oriental Region (ed., Delfinado, M. D. and D. E. Hardy), Vol. 3, pp. 270-274, The University Press of Hawaii, Honolulu.

Sabrosky, C. W. (1983) A synopsis of the world species of Desmometopa Loew (Diptera, Milichiidae). Contr. Amer. Ent. Inst., 19: 1-69.

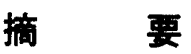

日本産クロコバェ属 (Genus Desmometopa)

(双翅目，クロコバェ科) について

岩佐光啓

帯広畜産大学畜産環境科学科昆虫学教室 （三080 帯広市稲田町西二線）

クロコバェ科 (Milichiidae) の Genus Desmometopa （クロコバェ属；新称）のハェの日本産の種については, 福原 (1965) が 3 種を記録して以来, 分類学的研究はな されていなかった，本報告では，いままで記録されてい た 3 種について次のように整理し，さらに 2 新記録種を 追加した. D. tarsalis Loew（ミナミクロコバエ）と同定 されていたものは D. microps Lamb で, D. tristicula Hendel（ヒメクロコバエ）と同定されていたものは $D$. sordida Fallén であることがわかった. また, D. palpalis de Meijere（ヤマトクロコバエ）は, 現在 D. singaporensis Kertész の synonym になっている，日本新記録 種は, D. m-nigrum (Zetterstedt)（ホホブトクロコバェ; 新称) とD. varipalpis Malloch (ナミクロコバェ; 新称) の 2 種であった. 日本産 5 種について特徴となる図とと もに再記載を加え，検索表を付した，本属の幼虫は腐食 性または賞食性で，鿓，堆肥，動植物質の腐敗物などか ら発生する. 成虫は人類親和性の種が含まれ，しばしば 大発生し, 食品工場や家屋, 病院の室内, トイレなどに 侵入することが知られている。 